\title{
EMPLOYEE INSTITUTIONAL TRUST AS AN ANTECEDENT OF DIVERSE DIMENSIONS OF ORGANISATIONAL COMMITMENT
}

The purpose of this study is to investigate the impact of the level of institutional trust upon employee commitment. Four types of organisational trust were taken into consideration: affective, normative, benefit-based and fear-based continuance. The influence of trust propensity upon the level of institutional trust was also tested. The survey was conducted in Poland on 444 randomly selected employees. Structural equation models were estimated confirming hypothesized relationships and explaining the substantial amount of variance of commitment measures. The research results allowed for verifying the model presenting relationships between institutional trust and commitment. The model indicates a significant impact of the institutional trust onto different types of organisational commitments, i.e. affective commitment, normative commitment, continuance benefit-based and fear-based commitment. In addition, the impact of trust propensity onto the degree of institutional trust of respondents was confirmed. The results of the study show that institutional trust in organisations must be developed in full awareness of its implications as the degree of the trust severely influences all types of organisational commitment, for this reason they should inspire management to actions aimed at growing the institutional trust. This study clearly demonstrates the importance of institutional trust as an organisational commitment-building factor. Up till now research was focused on the search for a relationship between the level of interpersonal trust and the level of organisational commitment, with regretfully little attention paid to institutional trust. The study confirmed the impact that institutional trust has on all four different types of organisational commitment, including two aspects of continuance commitment: benefit-based commitment and fear-based commitment, developed by the author.

Keywords: institutional (impersonal) trust, organisational commitment, human capital DOI: 10.15611 aoe.2020.1.13

\section{INTRODUCTION}

For nearly half a century the concept of organisational commitment has continued to attract the interest of management researchers and practitioners. Today, one may see a growing interest of researchers in analysing organisational commitment, which may be linked with the undersupply of

\footnotetext{
${ }^{*}$ AGH University of Science and Technology.
} 
talent to the labour market and the need to build a high quality work environment in organisations to attract and retain the most valuable employees (Reiche, 2008; Neininger et al., 2010; Meyer and Parfyonova, 2010; Yahaya and Ebrahim, 2016, Lewicka and Rakowska 2017, Rakowska 2018). This also results from the other benefits that come to an organisation through hiring organisationally committed employees. These benefits are, primarily, low absenteeism, turnover intention and turnover itself (Meyer et al., 2002; Labatmedienè et al., 2007, Addae et al., 2013, Meyer 2016), as well as a lower tendency for counterproductive behaviour (Marcus 2016) and enhanced task performance (Chen et al., 2006, Meyer et al., 2014), a higher tendency to demonstrate citizenship behaviour (Feather and Rauter, 2004; Zayas-Ortis et al. 2015; Stanley and Meyer 2016, Szostek and Glińska-Neweś, 2018) and many others. The above shows that organisational commitment is a variable which explains the behaviour and decisions taken by employees (Lewicka 2013, Kowalczyk 2014, Lewicka and Rakowska 2016).

Further to the above, researchers also focus on the organisational factors which affect the building or reinforcement of organisational commitment. These include organisational trust as a factor binding employees with the organisation. In turn, further to changes in contemporary organisations such as mergers, acquisitions or restructuring, the risk of losing trust in intraorganisational relations is also high, and this may cause very negative consequences for an organisation (Zeffane and Connell, 2003). Trust in intra-organisational relations is necessary in order to deliver projects (Grafe, 2012), since it influences improvement in collaboration (Sankowska, 2011), and the coordination of actions and productivity (Shockley-Zalabak et et al., 2000). In addition, it intensifies the exchange of knowledge and stimulates creative thinking since people who trust one another believe that the information they receive, even about their errors and mistakes, will not be used against them (Tyler, 2003).

Institutional trust from a management science perspective has become a subject of research and analysis as recently as in the last decade (Colquitt 2010, Bahman and Inkpen, 2011, Vanhala et al., 2011, Malkamäki et al.,2016), and so far only scant research has focused on the importance of institutional trust for building organisational commitment. In that context, interpersonal trust in an organisation and, in particular, the role of trust in the manager-subordinate relation was more focal.

For this reason the paper addresses the impact of institutional trust in the organisation onto different types of organisational commitment. Many 
employees pay certain financial and emotional costs when leaving their organisation. However, in most cases these are emotional costs of the fear of change, related to the degree of acceptance in a new work environment, adequacy of own competences when facing slightly different challenges as well as their concerns about compatibility of their own values with those professed in the new work environment. Further to the above, it was assumed that trust in the organisation is very likely to intensify the feeling of organisational commitment. This paper was written to demonstrate whether and to what extent trust affects different types of organisational commitment. This issue has become the axis of the research presented in the paper.

\section{ORGANISATIONAL COMMITMENT}

Researchers analysing organisational commitment are not in full agreement with regard to the meaning of the construct (Miller and Lee, 2001), as, with increasing frequency, commitment is also analysed in other relations, e.g. in relation to a team, line manager, clients or some specific actions e.g. goals, programmes, and initiatives (Becker 2016).Assuming that organisational commitment is the basis of an organisation, three main components can be distinguished: a cognitive, affective and behavioural component which may manifest themselves in a different way. Furthermore, the construct is classified to the so-called perceived and subjectively assessed constructs interpreted as conditions stimulated by the attitude of an individual towards the environment. Such feelings or conditions are largely subject to emotions and may be differently interpreted by respondents. To some degree, these two factors make interpretation of the research results difficult.

In this context it is worth mentioning the social exchange theory which helps to understand the mechanisms governing the development of attitudes towards an organisation, including organisational commitment (Vanhala et al., 2016). According to the theory, organisational commitment may be derived from the positive actions of an organisation and be a consequence of a positive outcome of an exchange between an employee and an organisation. On the part of the organisation the exchange may involve privileges, recognition, promotion and financial awards. Benefits received from the organisation trigger reciprocation which comes in the form of loyalty, commitment and citizenship behaviour. The feeling of imbalance may reduce commitment, weaken identification with the organisation, reinforce the intention to change employers, reduce the quality of 
performance, propensity for absenteeism and even propensity for unethical actions (Eisenberger et al., 2001, DeConinck and Stilwell, 2004, PeyratGuillard and Glińska-Neweś, 2010).

Many authors point to three factors characteristic for organisational commitment: identification with goals, standards and values of the organisation, engagement in delivering the objectives of the organisation and loyalty manifesting itself in the intention to remain in the organisation and act in its favour (Meyer et al., 2006).

Most works devoted to organisational commitment use the concept created by Meyer and Allen (1991) based on three components: affective, continuance, and normative. Affectively committed employees remain in the organisation by their own choice. The commitment is coupled with the feeling of satisfaction or even pride from being a member of the orga-nisation, as well as their conviction that they are willing to continue working for the organisation. Such commitment is strongly based on identification both with the goals and issues of the enterprise. Affectively committed employees may even claim that they feel at home at work. According to the literature, affective commitment is the most valuable for organisations since it affects employees' contribution and performance (Luchak and Gellatly, 2007).

Continuance commitment comes with the costs related to changing jobs that an employee experiences. The research carried out by this author indicates two components of continuance commitment: benefit-based commitment and fear-based commitment. They indicate a certain differentiation of motifs behind continuing with an organisation. In the case of benefit-based commitment, these are employment-related benefits perceived by the employee and based on the employee's calculation. These may be financial conditions, non-financial benefits but also the level of requirements. The study shows that such commitment creates the basis for developing affective commitment (Cohen, 2007, Lewicka and Krot, 2015) and that organisations draw some specific benefits when forging such commitment. In turn, fearbased commitment is related to perceiving the costs of leaving as high and undesirable which may be related to a subjective assessment of one's opportunities in the labour market or intention to reduce the fear of change. Certainly, both the above-described components are linked.

Normative commitment is linked with the feeling of duty to remain in an organisation and may be derived from the belief that work in an organisation comes with a mission or the feeling of an obligation to complete an important project, continue with the team, and so on. Research shows the existence of many determinants of the organisational commitment such as 
the characteristics of the organisation, job characteristics, and the role played in the organisation (Allen and Meyer, 1990). Nowadays many studies are devoted to analysing the relationship between organisational commitment and leadership (Yahaya and Ebrahim, 2016). In this context, the sociodemographics profiles of respondents are of importance, including such variables as sex, age and work experience.

\section{INSTITUTIONAL TRUST}

In the present economic reality, the higher importance of trust comes with an increasingly popular belief that trust is a rare but rather valuable resource for organisations, since trusted organisations can deal with complexity and uncertainty of economic reality (Bachmann and Zaheer, 2006). Only recently, institutional trust which is also referred to as impersonal trust (Vanhala et al., 2011) or system trust (Krot and Rudawska 2018), has been discovered as another research area. So far, academics interested in trust in organisations have focused on interpersonal trust (Abrams et al., 2003, Lewicki et al., 2006). However, an increasing number of research studies indicate that institutional trust may generate a competitive advantage (Vanhala et al., 2011) since is rather durable and continuous and not as fragile and fleeting as interpersonal trust. Even when interpersonal trust is undermined, institutional trust remains shock-resistant (Kramer, 1999, Shockley-Zalabak et al., 2000; Tyler, 2003). Institutional trust is created on the basis of the mission, strategy and goals of an organisation, effectiveness of management and fairness of the rules governing the operation of each level in the structure of the organisation and of the entire enterprise. The institutional dimension is built by the trust in the procedures, technologies and management system as it is linked with the belief that the organisation has some structural conditions that allow for achieving the planned goals. The processes occurring in the organisation are assessed by employees also in terms of the benefits that they may generate from being members of the organisation (Atkinson and Butcher, 2003). In this context it is important to perceive the organisation as fair and capable of recognising and adequately rewarding employees' contribution and creating opportunities for development (Tan and Tan, 2000; Vanhala et al., 2011). In light of the above, an important role in its development is attributed to HRM practices and processes (Whitener, 1997; Bijlsma and Koopman, 2003; Tyler, 2003; Tzafrir, 2005). Institutional solutions may reduce the risk of loss of trust. 
This may happen on the basis of applicable legislation, codes of conduct (sectoral and in-company codes and policies), goodwill, procedures, standards, formal and informal standards (Bachmann and Inkpen, 2011) accreditations, licenses which guarantee stability, security and predictability (Tschannen-Moran and Hoy, 2000).

Employees have institutional trust in the manner the enterprise is organised (procedures, technologies, management system, goals and vision), competences, policy and fairness (Ellonen et al., 2008). According to these authors, they consist of the following three factors:

- situational normality, based on the employees' belief that the enterprise operates as planned and everything seems to be working properly,

- structural certainty, interpreted as the belief in the success of the enterprise because appropriate conditions for its development have been guaranteed, i.e. contracts, regulations, agreements, strategies, etc.,

- vision, strategy and communication.

Similar conclusions were reached by the author of this paper who, on the basis of her empirical research, identified three similar dimensions of institutional trust: procedural certainty, feeling of security and effectiveness of communication (Krot and Lewicka, 2016). The literature mentions the particular importance of institutional trust for an organisation since it is the foundation for developing interpersonal trust. In their studies, Pennington et al. (2003) confirm that institutional trust comes before other types of trust. The impact of institutional trust on trust in managers is mentioned (McKnight and Chervany, 2001). It is also difficult to assume the emergence of highly performing teams with their members uninhibited in sharing knowledge while having no trust in the organisation (Svensson, 2006, Akgunet al., 2007, De Ortentiis, et al., 2013). To conclude, institutional trust creates the framework for building trust in vertical and horizontal relations.

\section{TRUST PROPENSITY}

Most authors believe that trust propensity is a personal feature which affects the degree of trust one has in specific objects (Meyer et al., 1995; Colquitt et al., 2007). An individual makes decisions on trusting or not trusting on the basis of trustworthiness signals, however in a new situation and absence of information, trust propensity becomes an excellent predictor of trust. Many authors emphasise that trust propensity does not guarantee trust in a specific situation but is a kind of filter used to evaluate the actions 
of others. On this basis, individuals make decisions on the degree of trust they may place in the other party. What is interesting is that the literature also mentions that propensity to trust is a dimension of trust equal to the cognitive and behavioural dimension (Costa et al., 2001). The issue of including trust propensity to trust-related research is growing in importance in the era of teamwork, the need for using the performance of others as the basis, but also due to the growing importance of inter-organisational relations (networks, alliances) for the success of the organisation. Trust propensity may enhance the propensity to build relations both inside and outside the organisation.

\section{HYPOTHESIS DEVELOPMENT}

The literature points to the positive relationship between the level of trust and organisational commitment (Dirks and Ferrin, 2001). As already mentioned, so far only scant research has been devoted to the impact of institutional trust on organisational commitment, however the limited research available offers a positive revision of the hypothesis on this impact (Vanhala et al., 2016; Lewicka and Krot 2015). Employees may cultivate all four forms of organisational commitment at different levels. What is more, the level of organisational commitment in each dimension may change in different periods of employment. Yet it seems that the level of impersonal trust may affect each type of organisational commitment, even more so that the type of trust is also the basis for creating interpersonal trust in an organisation (Pennigton et al., 2003). Further to the above the following research hypotheses were formulated referring to each type of organisational commitment.

H1: The institutional (impersonal) trust influences the level of commitment measured in the following dimensions: affective commitment, normative commitment, benefit-based and fear-based continuance commitment.

H1a: The affective commitment level is positively related to the level of institutional trust.

H1b: The benefit-based continuance commitment trust level is positively related to the level of institutional trust.

H1c: The fear-based continuance commitment trust level is positively related to the level of institutional trust.

H1d: The normative commitment level is positively related to the level of institutional trust. 
In addition, in this research approach, personality-related propensity to trust was taken into account as a factor that could influence the level of institutional trust.

$\mathrm{H} 2$ : Trust propensity level is positively related to the level of institutional trust.

\section{METHOD}

A quantitative approach was adopted based on the nature of the data. A structured questionnaire was used as the primary data collection instrument. The research involved conducting a survey among 444 employees of organisations and companies operating in Poland.

\subsection{Sample}

The data used in the paper come from a random sample representing the population of Poland aged $18+$ by using the Computer-Assisted Telephone Interviewing (CATI) method for quantitative research; the size of the sample was 1065 . Telephone numbers were randomly selected by using the assisted random digit dialling method. In addition, $70 \%$ of the mobile sample is randomly selected. Research respondents are also randomly selected from each selected layer. The layers (categories) correspond to the location size (9 categories), their regional distribution (16) and account for the age and sex of selected persons. The sampling process has several stages: stage one involves the stratification of the population of Poland based on the territorial location criterion and the class of the location size. The final stage of the research sample selection takes place during its telephone delivery. The IT system supervising the research receives both data on randomly selected telephone numbers as well as the estimated number of the layers (for the macro-regions as well as age, sex and location size categories). The computer randomly assigns telephone numbers to pollsters. At the initial phase of the interview, the pollster selects their respondents from the pool of available candidates by using the standard method and the system automatically supervises following the planned stratification. For the benefit of the study, the respondents were subject to an additional selection: first, data from persons who did not enjoy a working person status at the time of the survey were rejected; second, incomplete observations, i.e. missing data in the variables forming a part of the measurement model, were rejected. The owners',CEO's, and managing directors' replies were also removed from the sample. The sample structure shown in Table 1 was calculated for the sample $n=444$. 
Table 1

Research sample structure

\begin{tabular}{|c|c|c|c|c|c|}
\hline & Number & $\%$ & & Number & $\%$ \\
\hline \multicolumn{3}{|c|}{ Type of employment } & \multicolumn{3}{|c|}{ Sex } \\
\hline Contract for unspecified period & 321 & 72.3 & Women & 196 & 44.1 \\
\hline Contract for specified period & 123 & 27.7 & Men & 248 & 55.9 \\
\hline \multicolumn{3}{|l|}{ Ownership } & \multicolumn{3}{|c|}{ Position held } \\
\hline Private sector & 156 & 35.1 & Managerial staff & 94 & 21.2 \\
\hline Public sector & 139 & 31.3 & Specialist & 124 & 27.9 \\
\hline Partnership/ cooperative & 110 & 24.8 & Regular employee & 164 & 36.9 \\
\hline International company & 39 & 8.8 & Other & 62 & 14.0 \\
\hline & & & \multicolumn{3}{|c|}{ Seniority in the company } \\
\hline \multicolumn{3}{|c|}{ Education (background) } & Up to 3 years & 132 & 29.7 \\
\hline Primary & 10 & 2.3 & $4-8$ & 123 & 27.7 \\
\hline Vocational & 61 & 13.7 & $9-13$ & 62 & 14.0 \\
\hline Secondary & 171 & 38.5 & $14-18$ & 42 & 9.5 \\
\hline Higher & 202 & 45.5 & 19 and more & 82 & 18.5 \\
\hline \multicolumn{3}{|c|}{ Size of company (employees) } & I don't remember & 3 & .7 \\
\hline$\leq 10$ & 72 & 16.2 & \multicolumn{3}{|c|}{ Age brackets } \\
\hline $11-50$ & 130 & 29.3 & 18 to 24 & 33 & 7.4 \\
\hline $50-250$ & 105 & 23.6 & 25 to 34 & 122 & 27.5 \\
\hline $251-500$ & 36 & 8.1 & 35 to 44 & 135 & 30.4 \\
\hline$>500$ & 84 & 18.9 & 45 to 59 & 127 & 28.6 \\
\hline Hard to say & 17 & 3.8 & $\leq 60$ & 27 & 6.1 \\
\hline
\end{tabular}

Source: author's own.

\subsection{Measures}

The items in the questionnaire were developed by the author based on the studies of the authors listed in Table 2. Each of the studied dimensions was tested using containing statements to be evaluated on a five-point Likert scale.

Institutional (impersonal) trust (6 items) was measured with statements such as: "In my company, the company's principles and standards are observed"; "my company is well managed"; "in my company, conflicts are solved on an on-going basis". 
Table 2

Constructs

\begin{tabular}{l|l}
\hline \multicolumn{1}{c|}{ Construct } & \multicolumn{1}{c}{ Bibliographical sources } \\
\hline Institutional (impersonal) trust (6 items) & Ellonen et al., 2008 \\
\hline Continuance commitment benefit-based (3 items) & Lewicka 2014 \\
\hline Continuance commitment fear-based (3 items) & Lewicka 2014 \\
\hline Affective commitment (5 items) & Allen and Meyer, 1990 \\
\hline Normative commitment ( 6 items) & Allen and Meyer, 1990 \\
\hline Trust propensity ( 1 item) & Colquitt et al., 2007 \\
\hline
\end{tabular}

Source: author's own.

The affective commitment (5 items) was measured with the statements such as: "I do not think that I could be attached to another company as much as I am with the one I currently work for".

The normative commitment (6 items) was measured with the statements such as "I am convinced that one must be always loyal to their organisation", as well as those that strongly emphasised the obligations towards the company and the team, e.g.: "I know that my colleagues count on me and this is why, at the moment important for me and my team, I would not leave my work just like that", "I feel an internal obligation to work well every day not to let my colleagues down". "I would not take sick leave without a very good reason when the company needs me".

The fear-based continuance commitment was measured with the following statements: "I would be afraid to hand in my resignation if I was not certain that another organisation is going to hire me", "because of the situation in the labour market, I'd rather stay with my current employer". The benefit-based continuance commitment ( 3 items) was measured with the following statements: "at this moment of my life, it is to my benefit to remain with my employer", "the company gives me so many benefits that it does not payat the moment to look for another job", "benefits from working in this company are higher than disadvantages and inconveniences." Propensity to trust was analysed on the basis of the statement, "Most people can be trusted".

The measurement scales used in the measurement parts of estimated models are reliable and valid. Cronbach's alpha coefficient for institutional trust and affective and normative commitment exceeds the usually required value of 0.7 . For the rest of the constructs: benefit-based continuance commitment and fear-based commitment alphas are slightly below 0.7 , but in the first mentioned case the dimension consists of only 2 or 3 items, so 
alpha over 0.6 is required (Nunnally et al., 1967). Cronbach's alpha is the lower bound of true reliability (Peterson and Yeolib, 2013), so the requirements for reliable measurement have been met.

\subsection{Data analysis}

The presented analyses were made using the SPSS (version 22.0) statistical package and the AMOS 22.0 covariance-based structural equation modelling software. The path analysis approach to structural equations modelling was utilized with maximum likelihood estimation.

Table 3

Estimations of the SEM model parameters

\begin{tabular}{c|c|c|c|c|c|c|c}
\hline \multicolumn{3}{c|}{ Relationship } & $\begin{array}{c}\text { Model } \\
\text { coefficient }\end{array}$ & Beta & $\begin{array}{c}\text { Standard } \\
\text { error }\end{array}$ & $\begin{array}{c}\text { Wald's } \\
\text { statistics }\end{array}$ & $\mathrm{p}$-value \\
\hline Institutional trust & $\leftarrow$ & $\begin{array}{c}\text { Trust } \\
\text { propensity }\end{array}$ & 0.397 & 0.491 & 0.040 & 10.026 & $<0.000^{* *}$ \\
\hline $\begin{array}{c}\text { Normative } \\
\text { commitment }\end{array}$ & $\leftarrow$ & $\begin{array}{c}\text { Institutional } \\
\text { trust }\end{array}$ & 0.663 & 0.782 & 0.066 & 10.066 & $<0.000^{* *}$ \\
\hline $\begin{array}{c}\text { Continuance } \\
\text { commitment } \\
\text { fear-based }\end{array}$ & $\leftarrow$ & $\begin{array}{c}\text { Institutional } \\
\text { trust }\end{array}$ & 0.676 & 0.812 & 0.059 & 11.5 & $<0.000^{* *}$ \\
\hline $\begin{array}{c}\text { Continuance } \\
\text { commitment } \\
\text { benefit-based }\end{array}$ & $\leftarrow$ & $\begin{array}{c}\text { Institutional } \\
\text { trust }\end{array}$ & 0.639 & 0.583 & 0.074 & 8.69 & $<0.000^{* *}$ \\
\hline $\begin{array}{c}\text { Affective } \\
\text { commitment }\end{array}$ & $\leftarrow$ & $\begin{array}{c}\text { Institutional } \\
\text { trust }\end{array}$ & 0.614 & 0.757 & 0.057 & 10.845 & $<0.000^{* *}$ \\
\hline
\end{tabular}

** statistical significance at the level of 0.01

Source: author's own.

The results of the SEM model parameter estimation show that all the relations are statistically significant at the significance level of 0.01 . The assessment of the direction and strength (beta) of relationships is as follows:

- Propensity for trust has a positive, moderately strong impact on the institutional trust;

- Institutional trust has a positive and strong impact on the affective commitment;

- The institutional trust has a positive, strong impact on the benefit-based continuance commitment;

- The institutional trust has a positive, moderate impact on the fear-based continuance commitment;

- The institutional trust has a positive, strong impact on the normative commitment. 
Table 4

Correlation coefficients between variables

\begin{tabular}{l|c|c|c|c|c|c}
\hline & TP & IT & NC & F-BCC & B-BCC & AC \\
\hline Trust propensity & 1 & 0.491 & 0.372 & 0.286 & 0.398 & 0.384 \\
\hline Institutional trust & 0.491 & 1 & 0.757 & 0.583 & 0.812 & 0.782 \\
\hline Normative commitment & 0.372 & 0.757 & 1 & 0.565 & 0.614 & 0.625 \\
\hline Fear-based continuance commitment & 0.286 & 0.583 & 0.565 & 1 & 0.473 & 0.726 \\
\hline Benefit-based continuance commitment & 0.398 & 0.812 & 0.614 & 0.473 & 1 & 0.702 \\
\hline Affective commitment & 0.384 & 0.782 & 0.625 & 0.726 & 0.702 & 1 \\
\hline
\end{tabular}

Source: author's own.

The results presented in Table 4 confirm the directions and strengths of the relationships described in Table 3. The direct correlations between the elements of the theoretical construct are positive and moderate or strong.

Table 5

Standardised impact effects in the SEM model

\begin{tabular}{|c|c|c|c|c|c|c|}
\hline \multicolumn{7}{|c|}{ Total impact } \\
\hline & $\mathrm{TP}$ & IT & $\mathrm{NC}$ & F-BCC & $\mathrm{B}-\mathrm{BCC}$ & $\mathrm{AC}$ \\
\hline Institutional trust & 0.491 & 0 & 0 & 0 & 0 & 0 \\
\hline Normative commitment & 0.372 & 0.757 & 0 & 0 & 0 & 0 \\
\hline Fear-based continuance commitment & 0.286 & 0.583 & 0 & 0 & 0 & 0 \\
\hline Benefit-based continuance commitment & 0.398 & 0.812 & 0 & 0 & 0 & 0 \\
\hline Affective commitment & 0.384 & 0.782 & 0 & 0 & 0 & 0 \\
\hline \multicolumn{7}{|c|}{ Direct impact } \\
\hline & TP & IT & $\mathrm{NC}$ & F-BCC & $\mathrm{B}-\mathrm{BCC}$ & $\mathrm{AC}$ \\
\hline Institutional trust & 0.491 & 0 & 0 & 0 & 0 & 0 \\
\hline Normative commitment & 0 & 0.757 & 0 & 0 & 0 & 0 \\
\hline Fear-based continuance commitment & 0 & 0.583 & 0 & 0 & 0 & 0 \\
\hline Benefit-based continuance commitment & 0 & 0.812 & 0 & 0 & 0 & 0 \\
\hline Affective commitment & 0 & 0.782 & 0 & 0 & 0 & 0 \\
\hline \multicolumn{7}{|c|}{ Indirect impact } \\
\hline & TP & IT & $\mathrm{NC}$ & $\mathrm{F}-\mathrm{BCC}$ & $\mathrm{B}-\mathrm{BCC}$ & $\mathrm{AC}$ \\
\hline Institutional trust & 0 & 0 & 0 & 0 & 0 & 0 \\
\hline Normative commitment & 0.372 & 0 & 0 & 0 & 0 & 0 \\
\hline Fear-based continuance commitment & 0.286 & 0 & 0 & 0 & 0 & 0 \\
\hline Benefit-based continuance commitment & 0.398 & 0 & 0 & 0 & 0 & 0 \\
\hline Affective commitment & 0.384 & 0 & 0 & 0 & 0 & 0 \\
\hline
\end{tabular}

Source: author's own. 
Table 5 presents the results of assessing the relations among individual elements of the model presented in Figure 1. In the total impact, the propensity to trust has a moderate impact on the institutional trust, normative commitment, benefit-based continuance commitment and affective commitment. On the other hand, the impact on the fear-based continuance commitment was reported as weak. In turn, institutional trust has a moderately strong impact on the fear-based continuance commitment and a strong impact on other elements of the construct. The direct impact of the propensity for trust on institutional trust is moderately strong, while the direct impact of institutional trust on different types of commitment is strong, except for fearbased continuance commitment, for which it is moderate. The indirect impact of the propensity for trust onto different types of commitment is moderate except for fear-based continuance commitment, for which it is weak. Figure 1 presents the results of the study.

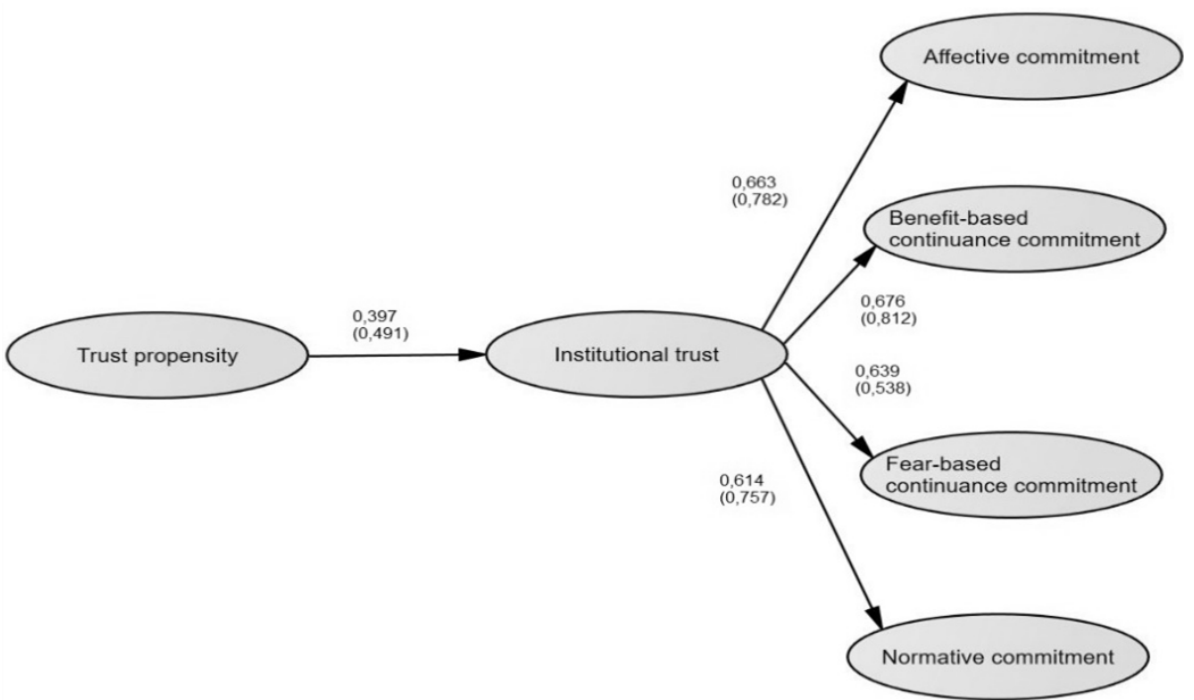

Fig. 1. The impact of institutional trust on the level of all types of organisational commitment

Source: author's own.

Each major SEM model may be accompanied by at most two other indices of fit, such as CFI (comparative fit index) and RMSEA (root mean square error of approximation) (Bentler, 2007). The estimated model measuring the institutional trust on the intensity of different types of 
commitment presented in Figure 1 fits well the collected empirical data. The results revealed 1.545 degrees of freedom with a probability level of $\mathrm{p}=0.00$. As the indicators show, the goodness-of-fit measures are satisfactory with both the GFI $=0.951$ and CFI $=0.974$, RMSEA $=0.035$ (Table 3 ).

Table 6

Model matching criteria

\begin{tabular}{l|c}
\hline \multicolumn{1}{c|}{ Model matching criteria } & Statistics \\
\hline CMIN/df & 1.545 \\
\hline RMR & 0.062 \\
\hline GFI & 0.951 \\
\hline AGFI & 0.924 \\
\hline CFI & 0.974 \\
\hline RMSEA & 0.035 \\
\hline PCLOSE & 0.999 \\
\hline
\end{tabular}

Source: author's own.

The results presented in the table above demonstrate the acceptability of the estimated model. The model appropriately implies the actual structure of the variance-covariance matrix among the construct components.

\section{DISCUSSION}

The results of the research show the importance that the institutional trust plays in developing the organisational commitment. One may conclude that its influence on the types of organisational commitment which are the most valuable for the organisation is the biggest. These would be, predominantly, affective commitment as, according to the research this commitment is the most affected by institutional trust. Affectively committed employees work harder, thus contributing to improving the overall performance of the organisation. They are also more prone to demonstrate citizenship behaviour (Colquitt et al., 2010). However, a negative work environment, including stress, absence of a work-life balance reduce the affective commitment, and these aspects of the work environment also reduce the level of institutional trust since they are symptomatic for inefficiently managed enterprises. The impact of institutional trust on benefit-based continuance commitment was only slightly lower. Organisations appreciate this type of commitment because, as mentioned above, it is very likely that this type of commitment 
precedes (creates the conditions for generating) the affective commitment (Cohen, 2007; Lewicka and Krot, 2015), which develops with time.

Furthermore, the research shows the impact of institutional trust on normative commitment. In this case, one may claim that normative commitment may be a consequence of the positive exchange between the organisation and an employee where the employee feels obligated to be loyal to the organisation (Allen and Meyer, 1990; Colquitt et al., 2010). Normative commitment seems of particular value for organisations as it may be triggered by deeply internalised reasons. The research also shows that the type of commitment has a positive influence on affective commitment (Meyer et al., 2002).

The research also proved the impact of institutional trust on fear-based organisational commitment. This type of organisational commitment does not seem entirely desirable by an organisation as it is often connected with passive attitude and performance which is barely acceptable. However, in the current economic reality, organisations strive rather to hire the best who can generate the added value for them. Yet this could be a benefit for organisations because of the cost efficiencies that come with training or selection of a new employee, in particular if the position does not require a particular initiative on their part.

The propensity to trust proved to exert a significant influence on the degree of institutional trust which confirms the need to include the variable when analysing trust.

\section{MANAGERIAL IMPLICATIONS}

The research results carry a series of implications to be considered by managers in organisations. First and foremost, the research results suggest the need for building institutional trust in an organisation since it affects the development of the types of organisational attachments which are beneficial for the organisation, its employees and, to some extent, also intensify their contribution to the development of the enterprise. Building institutional trust requires meticulous planning and well-thought strategy on the part of the organisation, including building its credibility and trustworthiness by developing the management systems, methods and procedures which allow for the stable and ethical operation of the enterprise. In addition, it is essential to promote coherent and clear values, communicate openly, care about keeping up standards of fairness, continually improve the quality of the work environment, building the feeling of support and conviction about 
the opportunities for development in the organisation. Employees should be made feel appreciated and valuable or even necessary for the organisation (Colquitt et al., 2010), which contributes to stimulating their normative commitment. In addition, the process of building institutional trust should be also oriented towards working outside the organisation, including involvement in solving local issues and environmental protection, offering high quality products and services, building long-term customer relations and a strong employee brand.

\section{LIMITATION OF THE STUDY AND FURTHER RESEARCH}

This study is not free from limitations, for example a limited scope of the sample related to the chosen research model and the nature of the analysed notions. The research was carried out in Polish conditions. It would be worthwhile to run a broader research in different cultural contexts as different countries have different levels of social trust and, possibly, different personal propensity to trust.

In the future, it would be worth testing, within a research model, the impact of both institutional and interpersonal trust to identify their influence on different types of organisational commitment. The relations identified in the model analysing the impact of the only type of trust onto different types of organisational commitment may be modified to some degree through contrasting impact of different types of trust when analysed jointly.

Another limitation is the subjectivity and declarative nature of analysed notions which refer to the respondents' observations. It could be worthwhile to enrich the future research approach with the quality approach emphasising the identification of respondents' behaviour resulting from the low or high degree of institutional trust.

\section{REFERENCES}

Abrams, L. C. Cross, R., Lesser E., Levin, D. Z., Nurturing interpersonal trust in knowledgesharing networks, „Academy of Management Executive”, Vol. 17, No. 4, pp. 65-77, 2003.

Addae, H. A., Johns, G., Boies, K., The legitimacy of absenteeism from work: A nine nation exploratory study, „Cross Cultural Management. An International Journal”, Vol. 20, No. 3, pp. 402-428, 2013.

Akgun, A.E., Keskin, H., Byrne, J., Imamoglu, S.Z., Antecedents and consequences of team potency in software development projects, „Information \& Management”, Vol. 44, No. 7, pp. 646-656, 2007. 
Allen, N.J., Meyer, J.P., The Measurement and Antecedents of Affective, Continuance and Normative Commitment to the Organization, „Journal of Occupational Psychology”, Vol. 63, pp. 1-18, 1990.

Atkinson, S., Butcher, D., Trust in managerial relationships, "Journal of Managerial Psychology", Vol. 18, pp. 282-304, 1990.

Bachmann, R., Inkpen, A. C., Understanding Institutional-based Trust Building Processes in Inter-organizational, „Relationships Organization Studies”, Vol. 2, No. 32, pp. 281-301, 2011.

Bachmann, R., Zaheer, A., Handbook of Trust Research. Edward Elgar Publishing Limited, Cheltenham, UK, Northampton, MA, 2006.

Becker, T. E., Multiple foci of workplace commitments, [in:] Meyer J. P. (ed.), Handbook of Employee Commitment, pp. 43-58, 2016.

Bijlsma, K., Koopman, P., Introduction: trust within organizations, „Personnel Review”, Vol. 32, pp. 543-555, 2003.

Brower, H. H., Schoorman, F. D., Tan, H. H., A model of relational leadership: the integration of trust and leader-member exchange, „Leadership Quarterly”, Vol. 11, No 2, pp. 227-250, 2000.

Chen, J., Silverthorne, C., Hung, J., Organization communication, job stress, organizational commitment, and job performance of accounting professionals in Taiwan and America, „Leadership \& Organization Development Journal”, Vol. 27, No. 4, pp. 242-249, 2006.

Cohen, A., Commitment before and after: An reconceptualization of organizational commitment, „Human Resources Management Review”, Vol. 17, pp. 336-354, 2007.

Colquitt, J. A., Scott, B.A., LePine, J.A., Trust, Trustworthiness, and Trust Propensity: A Meta-Analytic Test of Their Unique Relationships With Risk Taking and Job Performance, ,Journal of Applied Psychology”, Vol. 92, No. 4, pp. 909-927, 2007.

Colquitt, J. A., LePine, J. A., Wesson, M. J., Organizational Behavior: Essentials For Improving Performance and Commitment. McGraw-Hill Irwin, New York, NY, 2007.

Costa, A. C., Roe, R. A., Taillieu, T., Trust within teams: The relation with performance effectiveness, "European Journal of Work and Organizational Psychology", Vol. 10, No 3, pp. 225-244, 2001.

DeConinck, J.B., Stilwell, C.D., Incorporating organizational justice, role states, pay satisfaction and supervisor in a model of turnover intention, "Journal Business Reviews", Vol. 57, pp. 225-231, 2004.

De Ortentiis, P.S., Summers, J.K., Ammeter, A.P., Douglas, C., Ferris, G.R., Cohesion and satisfaction as mediators of the team trust-team effectiveness relationship: An interdependence theory perspective, „Career Development International”, Vol. 18, No. 5, pp. 521-543, 2013.

Dirks, K., Ferrin, D., The role of trust in organizational settings, „Organization Science”, Vol. 12, pp. 450-467, 2001.

Eisenberger, R., Armeli, S., Rexwinkel, B., Lynch, P.D., Rhoades, L., Reciprocation of perceived organizational suport, „Journal of Applied Psychology”, Vol. 86, pp. 42-51, 2001. 
Ellonen, R., Blomqvist, K., Puumalainen, K., The role of trust in organisational innovativeness, „European Journal of Innovation Management”, Vol. 11, No. 2, pp. 160-181, 2008.

Feather, N. T., Rauter, K. A., Organizational citizenship behaviour in relation to job status, job insecurity, organizational commitment and identification, job satisfaction and work values, „Journal of Occupational Psychology”, Vol. 77, No. 1, pp. 81-94, 2004.

Peyrat-Guillard, D., Glińska-Neweś, A., Positive Organizational Potential, Organizational Commitment and Organizational Citizenship Behaviour: A French/Polish Comparison, „Journal of Positive Management”, Vol. 1, No. 1, pp. 47-64, 2010.

Grafe, S., More Trust More Sales: Discover How You Can Build Trust to Better Sell. HuTrust, Victoria, Australia, 2012.

Kramer, R. M., Trust and distrust in organizations: emerging perspectives and enduring questions, „Annual Review of Psychology”, Vol. 50, pp. 569-98, 1999.

Krot, K., Lewicka, D., Zaufanie $w$ organizacji innowacyjnej, [Trust in an innovative organization]. C.H. Beck, Warsaw 2016.

Krot, K., Rudawska, I., Zaufanie jako zasób systemowy w sektorze zdrowia - w świetle badania polskich pacjentów [Trust as a systemic resource in the health sector - in light of the survey of Polish patients]. Studia Ekonomiczne. Zeszyty Naukowe Uniwersytetu Ekonomicznego w Katowicach, Vol. 350, No13, pp. 42-53, 2018.

Kowalczyk, E., Człowiek, organizacja, kariera. Siła psychologii stosowanej [Man, organization, career. The power of applied psychology]. Difin, Warsaw 2014.

Labatmedienè, L., Endriulaitienè, A., Gustainienè, L., Individual correlates of organizational commitment and intention to leave the organization, „Baltic Journal of Management”, Vol. 2, No. 2, pp. 196-212, 2007.

Lewicka, D., Wplyw zaufania wertykalnego na zaangażowanie organizacyjne pracowników [The impact of vertical trust on employee organisational commitment], „Acta Universitatis Lodziensis. Folia Oeconomica", Vol. 282, pp. 179-186, 2013.

Lewicka, D., The Influence of Organizational Trust upon Affective and Calculative Commitment, „The Journal of American Academy of Business, Cambridge”, Vol. 20, No. 1, pp. 205-212, 2014.

Lewicka, D., Krot, K., The model of HRM-trust-commitment relationships, „Industrial Management \& Data Systems", Vol. 115, No. 8, pp. 1457-1480, 2015.

Lewicka, D., Rakowska, A., Wpływ praktyk ZZL na zaangażowanie pracowników $w$ innowacyjnych przedsiębiorstwach [Impact of HRM practices on employee engagement in innovative companies], „Nauki o Zarządzaniu”, No. 2, pp. 102-115, 2016.

Lewicka, D., Rakowska, A., Calculative and affective commitment - the case study of the best Polish employer "Gaz Transmission Operator”, „Argumenta Oeconomica”, Vol. 39, No. 2, pp. 213-235, 2017.

Lewicki, R.J., Tomlinson, E.C., Gillespie, N. Models of interpersonal trust development: theoretical approaches, empirical evidence, and future directions, „Journal of Management”, Vol. 32, No 6, pp. 991-1022, 2006.

Luchak, A.A., Gellatly, I.R. A comparison of linear and nonlinear relations between organizational commitment and work outcomes, „The Journal of Applied Psychology”, Vol. 92, No. 3, pp. 786-793, 2007. 
Marcus, B., Counterproductive work behaviours, [in:] Meyer, J.P. (ed.), Handbook of Employee Commitment, pp. 222-234, 2016.

Malkamäki, K., Ikonen, M., Savolainen, T, Process of trust building: a case study in the management system context, [in:] Jagd, S., Fuglsang, L. (eds.), Trust, Organizations and Social Interaction. Studying Trust as Process within and between Organizations, pp. 146-166, 2016.

Mayer, R. C., Davis, J. H., Schoorman, F.D., An integrative model of organizational trust, „Academy of Management Review”, Vol. 20, pp.709-734, 1995.

McKnight, D. H., Chervany, N. L., Trust and Distrust Definitions: One Bite at a Time, [in:] Trust in Cyber-societies. Springer Verlag, Berlin-Heidelberg 2001.

Meyer, J. P., Allen, N. J., A three-component conceptualization of organizational commitment, „Human Resource Management Review”, Vol. 1, No. 2, pp. 61-89, 1991.

Meyer, J. P., Herscovitch, L., Commitment in the workplace: toward a general model, „Human Resource Management Review”, Vol. 11 No. 4, pp. 299-326, 2001.

Meyer, J. P., Stanley, D. J., Herscovitch, L., Topolnytsky, L., Affective, continuance, and normative commitment to the organization: a meta-analysis of antecedents, correlates, and consequences, ,Journal of Vocational Behavior”, Vol. 61, No. 1, pp. 20-52, 2002.

Meyer, J. P., Parfyonova, N. M., Normative commitment in the workplace: a theoretical analysis and re-conceptualization, „Human Resource Management Review”, Vol. 20, No. 4, pp. 283-294, 2010.

Meyer J. P., Employee commitment - looking back and moving forward, [in:] Meyer J.P. (ed.) Handbook of Employee Commitment, pp. 511-528, 2016.

Miller, D., Lee, J., The people make the process: commitment to employees, decision making and performance, ,Journal of Management”, Vol. 27, pp. 163-189, 2001.

Neininger, A., Lehmann-Willenbrock, N., Kauffeld, S., Hensche, A.C., Effects of team and organizational commitment - A longitudinal study, „Journal of Vocational Behavior”, Vol. 47, pp. 22-37, 2010.

Pennington, R., Wilcox H. D., Grover V., The Role of System Trust in Business-to-Consumer Transactions, „Journal of Management Information”, Vol. 20, No 3, pp. 197-226, 2003.

Peterson, R. A., Yeolib, K., On the Relationship Between Coefficient Alpha and Composite Reliability, „Journal Of Applied Psychology”, Vol. 98, No. 1, pp. 194-1982, 2013.

Reiche, B. S., The configuration of employee retention practices in multinational corporations' foreign subsidiaries, „International Business Review”, Vol. 17, No. 6, pp. 676-687, 2008.

Rakowska, A. (ed.), Unlocking the Potential of Employees in the Context of Organizational Diversity. ToKnowPress, Bangkok-Celje-Lublin 2018.

Sankowska, A., Wplyw zaufania na zarzqdzanie przedsiębiorstwem. Perspektywa wewnatrzorganizacyjna, [The impact of trust on company management. An intra-organisational perspective], Difin, Warszawa 2011.

Shockley-Zalabak, P, Ellis, K, Winograd, G., Organizational trust: what it means, why it matters, „Organization Development Journal”, Vol. 18, No. 4, pp. 35-48, 2000.

Stanley, D. J., Meyer, J. P., Employee commitment and performance, [in:] ed. Meyer, J.P., Handbook of Employee Commitment, pp. 208-22, 2016. 
Svensson, G., Multiple informants and asymmetric interactions of mutual trust in dyadic business relationships, „European Business Review”, Vol. 18, No. 2, pp. 132-152, 2006.

Szostek, D., Glińska-Neweś, A., Organizational Citizenship Behaviors in Public and Private Sector, „International Journal of Contemporary Management”, Vol. 1, pp. 45-58, 2018.

Tan, H. H., Tan, C. S. F., Toward the differentiation of trust in supervisor and trust in organization, „Genetic, Social, and General Psychology Monograph", Vol. 126, No. 2, pp. 241-260, 2000.

Tschannen-Moran, M., Hoy, W. K., A multidisciplinary analysis of the nature, meaning, and measurement of trust, „Review of Educational Research”, Vol. 70, No. 4, pp. 547-593, 2000.

Tyler, T. R., Trust within organisations, „Personnel Review”, Vol. 32, No. 5, pp. 556-568, 2003.

Tzafrir, S. S., The relationship between trust, HRM practices and firm performance, „International Journal of Human Resource Management”, Vol. 16, pp. 1600-1622, 2005.

Vanhala, M., Puumalainen K., Blomqvist K., Impersonal trust. The development of the construct and the scale, „Personnel Review”, Vol. 40, No. 4, pp. 485-513, 2011.

Vanhala, M., Heilmann P., Salminen H., Organizational Trust Dimensions as Antecedents of Organizational Commitment, „Knowledge and Process Management”, Vol. 23, No. 1, pp. 46-61, 2016.

Yahaya, R., Ebrahim F., Leadership styles and organizational commitment: literature review, „Journal of Management Development”, Vol. 35, No. 2, pp. 190-216, 2016.

Zayas-Ortiz M., Rosario E., Marquez E., Colón Gruñeiro P.C., Relationship between organizational commitments and organizational citizenship behaviour in a sample of private banking employees, „International Journal of Sociology and Social Policy”, Vol. 35, No.1/2, pp. 91-106, 2015.

Zeffane R, Connell J., Trust and HRM in the new millennium, „International Journal of Human Resource Management”, Vol. 14, No. 1, pp. 3-11, 2003.

Received: May 2017, revised: May 2019 